\title{
Thermal Structure of the Outer Northern Apennines along the CROP-03 Profile
}

\author{
Stefano Santini ${ }^{1}$, Stefano Mazzoli ${ }^{2}$, Antonella Megna ${ }^{3} \&$ Stefania Candela ${ }^{1}$ \\ ${ }^{1}$ Dipartimento di Scienze di Base e Fondamenti (DiSBeF), University of Urbino, Via Santa Chiara 27, 61029 \\ Urbino, Italy \\ ${ }^{2}$ Dipartimento di Scienze della Terra, dell'Ambiente e delle Risorse (DiSTAR), Università di Napoli Federico II, \\ Largo San Marcellino 10, 80138 Napoli, Italy \\ ${ }^{3}$ Istituto Nazionale di Geofisica e Vulcanologia (INGV), Sezione di Sismologia e Tettonofisica, Via di Vigna \\ Murata 605, 00143 Roma, Italy \\ Correspondence: Stefano Santini, Dipartimento di Scienze di Base e Fondamenti (DiSBeF), University of Urbino, \\ Via Santa Chiara 27, 61029 Urbino, Italy. Tel: 39-0722-303-390, Fax: 39-0722-303-399. E-mail: \\ santini@fis.uniurb.it
}

Received: September 24, 2016

Accepted: November 18, 2016

Online Published: November 18, 2016

doi:10.5539/jgg.v8n4p1

URL: http://dx.doi.org/10.5539/jgg.v8n4p1

\begin{abstract}
In this study, we elaborated a 2D model that reproduces the thermal structure of the central-northern Adriatic offshore and adjacent onshore area of the Italian peninsula. Based on the crustal structure along the trace of the CROP-03 deep section, the geotherms offshore Gabicce (northern Marche region) were obtained by an analytical procedure taking into account the role of thrusting within the sedimentary cover. Basement involvement at depth beneath the neighbouring Mondaino area to the SW, where a crustal thrust ramp dips towards the hinterland, required the use of a different analytical procedure. The results obtained in this study allowed us to define a satisfactory description of the thermal state of the northern Marche coastal area and adjacent Adriatic offshore. These results, integrated with those obtained by previous studies, confirm that the isotherms of $250^{\circ} \mathrm{C}$ and $400^{\circ} \mathrm{C}$ are placed in the stable Adriatic lithosphere at depths of about $11 \mathrm{~km}$ and $22 \mathrm{~km}$, respectively. Furthermore, the $400^{\circ} \mathrm{C}$ isotherm is deeper in the onshore area, reaching a depth of about $30 \mathrm{~km}$ in the zone comprised between Gabicce and Mondaino, whereas the $250^{\circ} \mathrm{C}$ isotherm deepens towards the SW along the Adriatic Sea sector, to reach a maximum depth of $13 \mathrm{~km}$ in coastal area, rising again at a depth of $11 \mathrm{~km}$ in the innermost sector of the studied section.
\end{abstract}

Keywords: central Adriatic offshore, northern Marche onshore, surface heat flow, thermal modeling, temperature profiles

\section{Introduction}

The deep structure and active tectonic setting of the outer northern Apennines are widely debated, particularly concerning two main issues: (i) the degree of basement involvement in shortening (i.e. 'detachment-dominated', or thin-skinned, vs. 'crustal-ramp-dominated', or thick-skinned, styles of thrusting; e.g. Bally et al., 1986; Barchi et al., 1998; Coward et al., 1999; Mazzoli et al., 2001, 2005; Speranza \& Chiappini, 2002), and (ii) the role and extent of thrust activity (i.e. thrusting- vs. strike-slip-dominated active stress field; e.g. Di Bucci et al., 2003; Vannoli et al., 2004; Basili \& Barba, 2007; Santini et al., 2011; Kastelic et al., 2013; Mazzoli et al., 2014, 2015). Improving our understanding of the rheology of this sector of the Apennine orogen is fundamental in order to carry out meaningful seismotectonic analysis and modeling. Taking into account that rheology depends on the thermal model that is assumed, this paper aims at defining the thermal structure of the outer northern Apennines. To this purpose, geothermal modeling is carried out along a cross-section integrating the interpreted CROP 03 deep seismic reflection profile (Barchi et al., 1998) and the structure of the adjacent Adriatic offshore sector (Morgante et al., 1998; Coward et al., 1999; Mazzoli et al., 2001).

\section{Geological setting}

2.1 Stratigraphy

Deep parts of the Apennine stratigraphy are known from deep wells. These, on top of crystalline basement units, 
penetrated Permo-Triassic continental siliciclastic deposits (i.e. the Verrucano Group). The overlying UmbriaMarche succession consists mainly of carbonates (Upper Triassic-Eocene), displaying significant vertical and lateral variations of both facies and thickness of the formations (Figure 1a) and recording Jurassic rifting and subsequent development of a passive continental margin. Both rift-related 'complete' and 'condensed' successions are stratigraphically overlain by uppermost Jurassic to Oligocene limestones and marls of the Maiolica and Marne a Fucoidi Fms., and by the Scaglia Group. The stratigraphically overlying hemipelagic, turbiditic and also evaporitic units of Miocene-Pliocene age include the marker horizons of the Bisciaro (Lower Miocene) and Gessoso-Solfifera (Messinian) Fms.. In the Marche foothills and Adriatic offshore areas, the deformed Mesozoic-Paleogene sequence is mostly buried beneath these Miocene-Pliocene strata (Figure 1b).
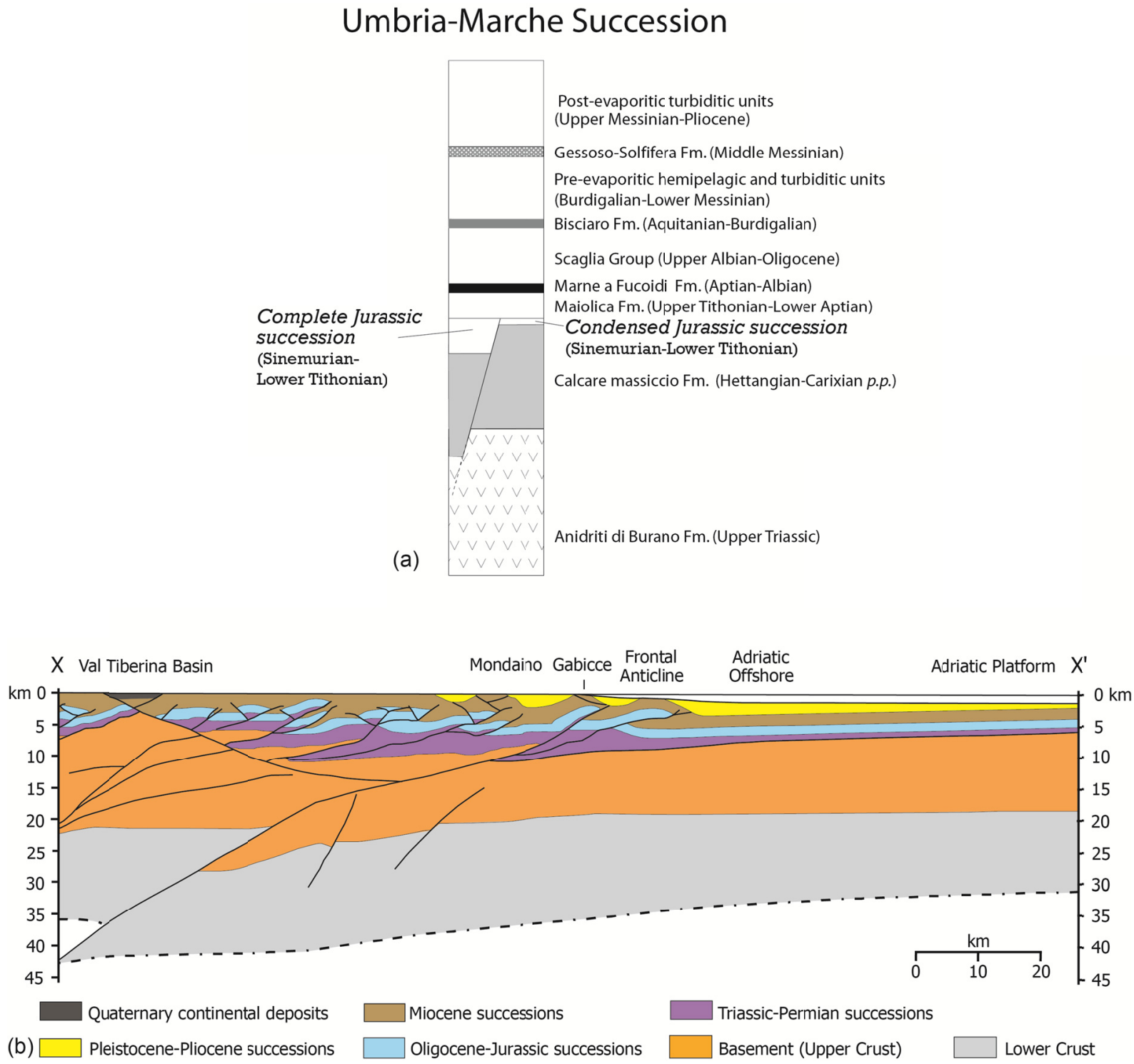

Figure 1. (a) Schematic stratigraphy of the study area (from Mazzoli et al., 2005). (b) Geological cross-section (modified after Barchi et al., 1998; Morgante et al., 1998; located in Figure 2)

\subsection{Tectonics}

The outer northern Apennines (Figure 2) are characterised by an arcuate shape and a main northeast vergence of asymmetric, mostly faulted anticlines involving Mesozoic-Tertiary sedimentary successions (e.g. Mazzoli et al., 2005, and references therein). The Upper Triassic evaporites form an important structural decoupling horizon so that the underlying strata remain buried. Other levels within the Mesozoic and Cenozoic successions are also thought to have acted as thrust flats locally, particularly shales and marls within the otherwise 
carbonate-dominated units (e.g. Barchi et al., 1998). At depth, the siliciclastic deposits of the Verrucano Group overlie crystalline basement units that are shown in Figure 1 as being also involved in thick-skinned thrusting (Coward et al., 1999; Mazzoli et al., 2001), as confirmed by the interpretation of the CROP 03 deep seismic reflection profile (Barchi et al., 1998). This is at variance with previous interpretations of thin-skinned thrusting that were mainly based on magnetic data modelling providing a uniformly and gently W-dipping 'magnetic basement' (e.g. Bally et al., 1986). As a matter of fact, new magnetic data and modelling indicate basement involvement in thrusting (Speranza \& Chiappini, 2002; Tozer et al., 2006).

In the Marche foothill area and adjacent Adriatic offshore, the deformed Mesozoic-Paleogene multilayer is mostly buried beneath such recent strata.

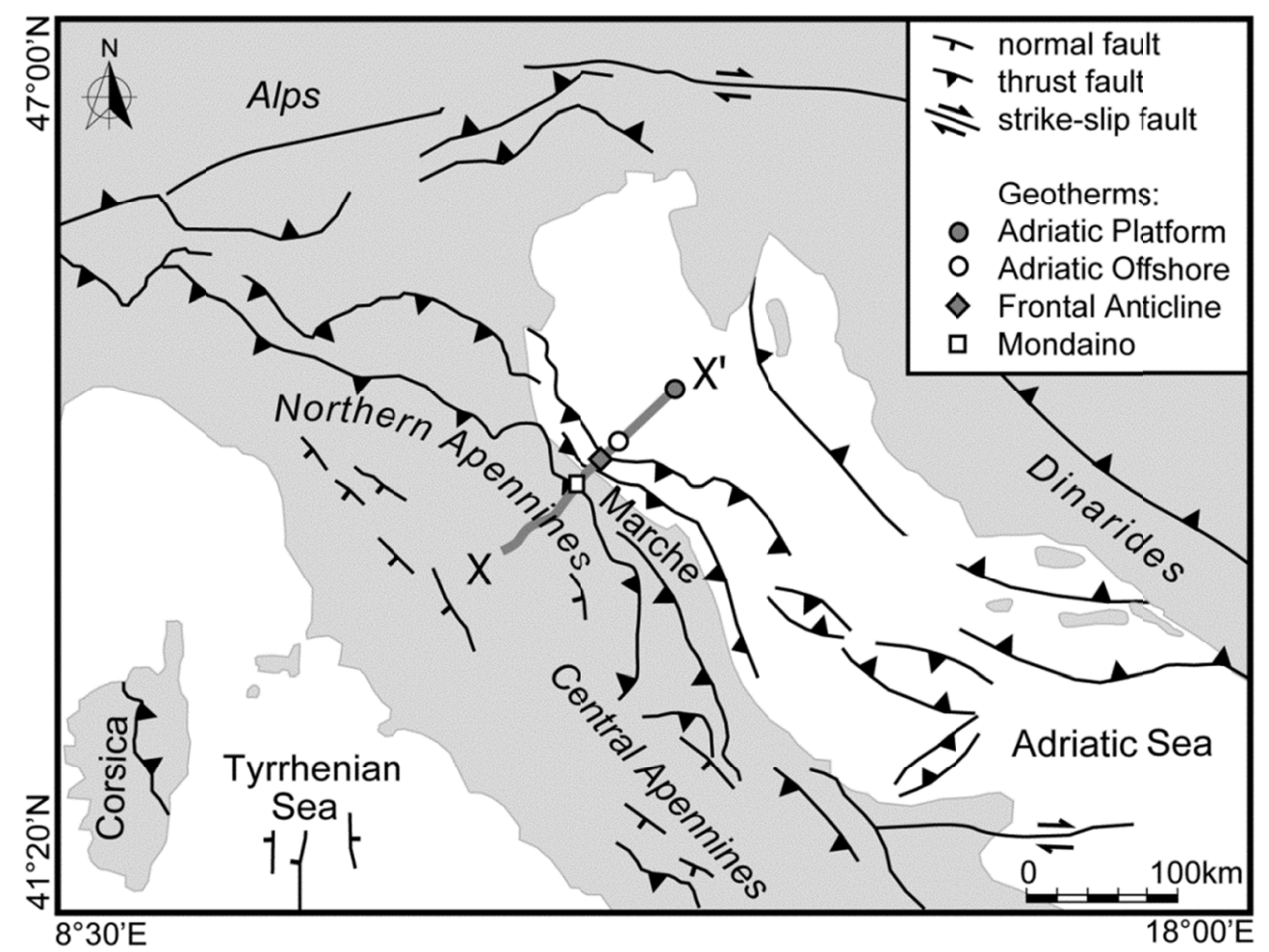

Figure 2. Tectonic sketch map of CROP-03 profile (after Barchi et al., 2003, modified) showing location of the crustal cross-section $\mathrm{X}-\mathrm{X}^{\prime}$

Late Quaternary thrust activity in this frontal part of the belt is widely debated (DISS Working Group, 2010; Mazzoli et al., 2015, and references therein). Timing of the deformation has been obtained by Coward et al. (1999) and Di Bucci et al. (2003) based on the detailed analysis of syntectonic growth strata imaged on seismic profiles calibrated with well logs. These studies indicate 1.8 My-long activity (between 2.5 and $0.7 \mathrm{Ma}$ ) for the thrust splay underlying the Mondaino site in Figure 2, and 1.1 My-long activity (from 1.8 to $0.7 \mathrm{Ma}$ ) for the thrust splay carrying the Frontal Anticline. However, it is worth noting that the whole thrust system including the two splays analysed here is elsewhere considered as presently active and seismogenic (e.g. DISS Working Group, 2010).

\section{Methods}

The analytical procedure applied in this study takes into account both the temperature variation due to the re-equilibrated conductive state after thrusting and frictional heating. Input parameters include heat flow density data and a series of geologically derived constraints. The map of the heat flow density in Italy by Scrocca et al. (2003) is used to constrain surface heat flow in the study area. In order to perform the temperature calculations, the crustal structure of the study area has been simplified as composed of two units: (i) an upper unit that includes all sedimentary layers from the Pleistocene to the Permo-Triassic; and (ii) a lower unit that includes the upper crust (orogenic basement) and the lower crust (Figure 3).

The fundamental heat sources to be considered in the computations include both the heat rising from the mantle 
and the radiogenic heat due to the presence of radioactive elements in the lower unit. In fold and thrust belts such as the Apennines, a further heat source is represented by frictional heating associated with thrust faulting. The computing procedure follows the procedure developed by Molnar et al. (1983), which defines the temporal evolution of the thermal state as the sum of two terms:

$$
T(z, t)=T_{f}(z)-\theta(z, t)
$$

the new equilibrium final state and a time dependent term:

$$
\theta(z, t)=\sum_{n=0}^{\infty} A_{n} \sin \left(a_{n} z\right) e^{-a_{n}^{2} K t}
$$

defined by the perturbed initial state:

$$
A_{n}=\frac{2}{h} \int_{0}^{h} \theta(z, 0) \sin \left(a_{n} z\right) d z
$$

with $a_{n}=(2 n+1) \pi / 2 h$.

The two terms $\mathrm{T}_{\mathrm{f}}$ and $\theta$ depend on the heat source type, the thrust depth $\left(\mathrm{z}_{0}\right)$, the crustal thickness (h), the thermal capacity $(\mathrm{k})$ and diffusivity $(K)$.
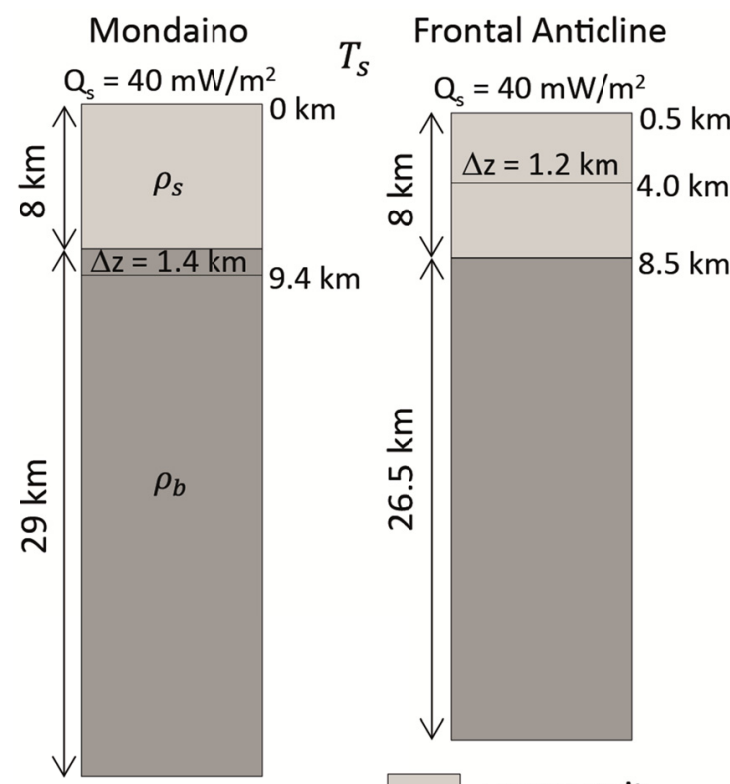

\section{Adriatic Offshore}

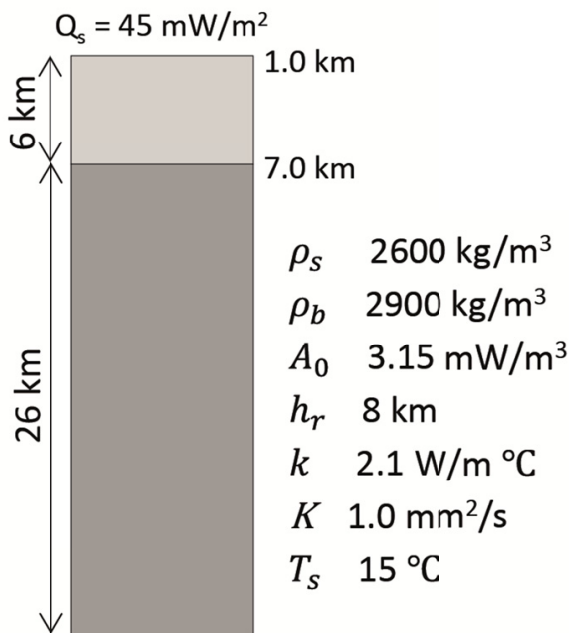

upper unit

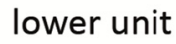

Figure 3. Schematic crustal model for geotherm calculation along the CROP-03 profile (located in Figure 2). The parameters are: density of upper $\left(\rho_{s}\right)$ and lower unit $\left(\rho_{b}\right)$, radiogenic heat $\left(A_{0}\right)$ and its length scale $\left(h_{r}\right)$, thermal conductivity $(\mathrm{k})$ and diffusivity $(K)$, crustal thickening $(\Delta \mathrm{z})$, surface heat flow $\left(Q_{s}\right)$, surface temperature $\left(\mathrm{T}_{\mathrm{s}}\right)$

For a thrust occurring at a depth $z_{0}$ at a site of geotherm calculation, a crustal thickening $\Delta z$ is taken into account in the computations by carrying out a simple restoration based on offset stratigraphy, as shown in Candela et al. (2015) and Megna et al. (2014). The procedure is different in case crustal thickening occurs only by shortening of the sedimentary cover, or in case it involves also the basement along the vertical profile of geotherm calculation. In the former case, the flow of radiogenic heat is unchanged (so $T_{r h}$ ), whereas the thermal state $T_{m h}$ due to unitmantel heat flow is modified with a temperature jump in correspondence of the thrust. At the initial time of thrusting $(\mathrm{t}=0)$, the temperature jump corresponds to the difference $\Delta T$ between the temperature at thrust depth $z_{0}$ and that at the depth $z_{0}-\Delta z$ (Megna et al., 2014). For $t>0$, the temperature evolves until reaching the new equilibrium state for $t \rightarrow \infty$. At these two heat flows must be added the flow of frictional heat $T_{f h}$. The thermal state for the two units is defined by the following equations:

$$
\begin{array}{rc}
T(z, t)=T_{s}+T_{m h}(z, t)+T_{f h}(z, t) & z \leq D_{1}, \\
T(z, t)=T_{s}+T_{m h}\left(D_{1}, t\right)+T_{f h}(z, t)+T_{r h}(z) & z>D_{1},
\end{array}
$$

where $T_{s}$ is the surface temperature, $D_{1}$ is the thickness of the upper unit, and $T_{m h}\left(D_{1}, t\right)$ is the temperature at the bottom of the sedimentary cover. 
In the case of a thrust fault involving the basement along the vertical profile of geotherm calculation, thrusting causes a perturbation to thermal state due to mantle-derived heat flow and to radiogenic heat flow. Furthermore, for the calculation of the thermal state of upper unit $\left(T_{d h}\right)$ the increase of radiogenic heat associated with the increased basement thickness $(\Delta z)$ must be taken into account (Candela et al., 2015). Also in this case, the flow of frictional heat $T_{f h}$ must be added to the other two heat flow components. The temperature for the two units is obtained by the following equations:

$$
\begin{array}{cr}
T(z, t)=T_{s}+T_{d h}(z, t)+T_{f h}(z, t) & z \leq D_{1}, \\
T(z, t)=T_{s}+T_{d h}\left(D_{1}, t\right)+T_{m h}(z, t)+T_{r h}(z, t)+T_{f h}(z, t) & D_{1}<z \leq h .
\end{array}
$$

In both cases, each term depending on time has the generic equation (1), where $T_{f}(z)$ is the final temperature of the new equilibrium status $(t \rightarrow \infty)$ and $\theta(z, t)$ is calculated by equations (2) e (3). $T_{f}(z)$ and $\theta(z, t)$ show differences due to thermal source type and depending on thrusting involving the sedimentary cover (Megna et al., 2014) or the basement along the vertical profile of geotherm computation (Candela et al., 2015).

\section{Results}

Representative geotherms for the study area are calculated along three vertical profiles through the crust of the outer northern Apennines. Two geotherms are calculated for the onshore (Mondaino) and offshore (Frontal Anticline) sectors of the frontal part of the fold and thrust belt (Figure 2). To complete the treatment, a further geotherm is calculated in the foreland basin (Adriatic Offshore) at about $30 \mathrm{~km}$ from the coastline. The interpolated isotherms are then extended to the geothermal profile calculated by Mongelli et al. (2006) further offshore (Adriatic Platform).

The map by Scrocca et al. (2003) was used to constrain surface heat flow in the study area. The two innermost sites of geotherm computation (i.e. Mondaino and Frontal Anticline) fall close to the contours of $40 \mathrm{~mW} / \mathrm{m} 3$ in the map, whereas the site Adriatic Offshore sits in an area of heat flow $>40 \mathrm{~mW} / \mathrm{m} 3$. Based on their position with respect to the heat flow contours, we chose a value of $40 \mathrm{~mW} / \mathrm{m} 3$ for both the Mondaino and Frontal Anticline geotherms, and a $Q_{s}$ of $45 \mathrm{~mW} / \mathrm{m} 3$ for the Adriatic offshore geotherm.

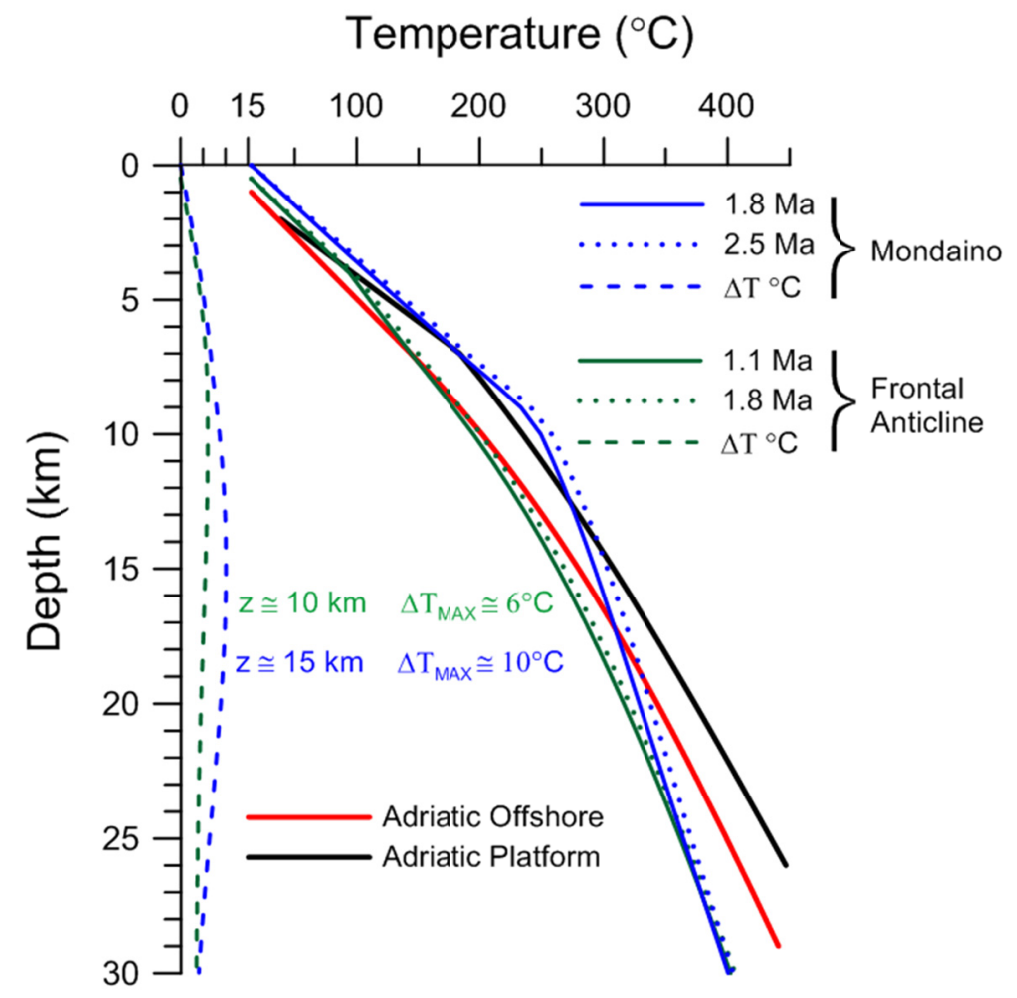

Figure 4. Calculated geotherms and temperature profile for the Adriatic Platform (Mongelli et al., 2006). For the Mondaino (blue) and Frontal Anticline (green), geotherms for the two activity periods of thrusting are shown, together with their respective temperature difference profiles $(\Delta T) 3.5$ times enlarged in the temperature scale 
For the Mondaino site, the geotherm has been calculated taking into account a dip separation of $9 \mathrm{~km}$ (measured at top-basement level) along the thrust fault, producing a crustal thickening $(\Delta z)$ of $1.4 \mathrm{~km}$ along the vertical profile of geotherm computation (Figure 3). A crustal thickening $(\Delta z)$ of $1.2 \mathrm{~km}$ is produced along the vertical profile of geotherm computation for the Frontal Anticline, the underlying thrust having a dip separation of $8 \mathrm{~km}$ (measured at top-Oligocene level). Taking into account the continuing debate about thrust activity/inactivity in the outer portion of the northern Apennines in the study area, two different geotherms have been calculated for each of the two sites located in the frontal part of the thrust belt. For the Mondaino site, temperature profiles have been obtained for a timing of activity $(\Delta \mathrm{t})$ of $1.8 \mathrm{Ma}$ (i.e. between 2.5 and $0.7 \mathrm{Ma}$, as suggested by seismic stratigraphic evidence), and for $\Delta \mathrm{t}=2.5 \mathrm{Ma}$ (i.e. assuming its present-day activity). Similarly, for the Frontal Anticline site, temperature profiles have been obtained for a $\Delta \mathrm{t}$ of $1.1 \mathrm{Ma}$ (i.e. between 1.8 and $0.7 \mathrm{Ma}$ ), and $\Delta \mathrm{t}$ $=1.8 \mathrm{Ma}$ (i.e. assuming it is presently active). Shear heating has been obtained, based on Sibson's (1974) formulation for frictional heating, using the calculation adopted in Candela et al. (2014) with a friction coefficient equal to 0.6. All further parameters required to define each geotherm are shown in Figure 3.

\section{Discussion and concluding remarks}

Our results show that, for the upper unit of the crust, the geotherms obtained for the Frontal Anticline and Adriatic Offshore sites differ essentially around the depth $(4 \mathrm{~km})$ of the thrust fault encountered along the vertical profile of the former, mainly due to the contribution of frictional heating. For the Mondaino site, the contribution of both frictional heating and radiogenic heat associated with basement-involved thrusting is clearly recorded by the temperature profile at the depth of the thrust $(\mathrm{ca} .9 \mathrm{~km})$. On the other hand, the geotherms obtained by assuming a different timing of activity of the thrust system differ only slightly for a single site, reaching maximum values of $6{ }^{\circ} \mathrm{C}$ (at ca. $10 \mathrm{~km}$ depth) and $10{ }^{\circ} \mathrm{C}(\mathrm{ca} .15 \mathrm{~km})$ for the Frontal Anticline and Mondaino sites, respectively (Figure 4). This is because frictional heating is proportional to slip velocity; therefore, for a constant total fault displacement, the effect of frictional heat production over longer periods of time is counterbalanced by higher slip rates in case of shorter times of fault activity. As a result, the isotherms produced by the interpolation of the vertical temperature profiles define a thermal structure for the study area (Figure 5) that is almost independent of thrust activity or quiescence during the late Quaternary (i.e. since 0.7 $\mathrm{Ma})$.

Our modelling results show that the thermal structure of the study area is consistent with a "crustal-rampdominated' (Butler \& Mazzoli) style of thrusting. The modelled geotherms, obtained by including basement thrusts in the computations, fit satisfactorily the available constraints in terms of measured heat flow in the study area. On the other hand, our results indicate that the occurrence - or lack - of active thrusting in the late Quaternary is negligible in terms of thermal effects. Therefore, thermal modelling cannot provide independent constraints on the ongoing debate on the active deformation and seismotectonics of the outer northern Apennines. However, it is well known that defining the thermal setting is fundamental in rheology studies and numerical modeling of tectonic processes (e.g. Candela et al., 2015). Therefore, the thermal structure obtained in this study can be used in any modelling studies aimed at improving our understanding of active deformation in the frontal part of the northern Apennines. More in general, any quantitative modeling of geodynamic processes affecting the study area, and requiring the definition of rheological parameters, can be carried out by taking into account the thermal structure obtained in this study, irrespective of tectonic interpretations involving the occurrence or lack of active thrusting in the Adriatic sector of the frontal part of the northern Apennines.

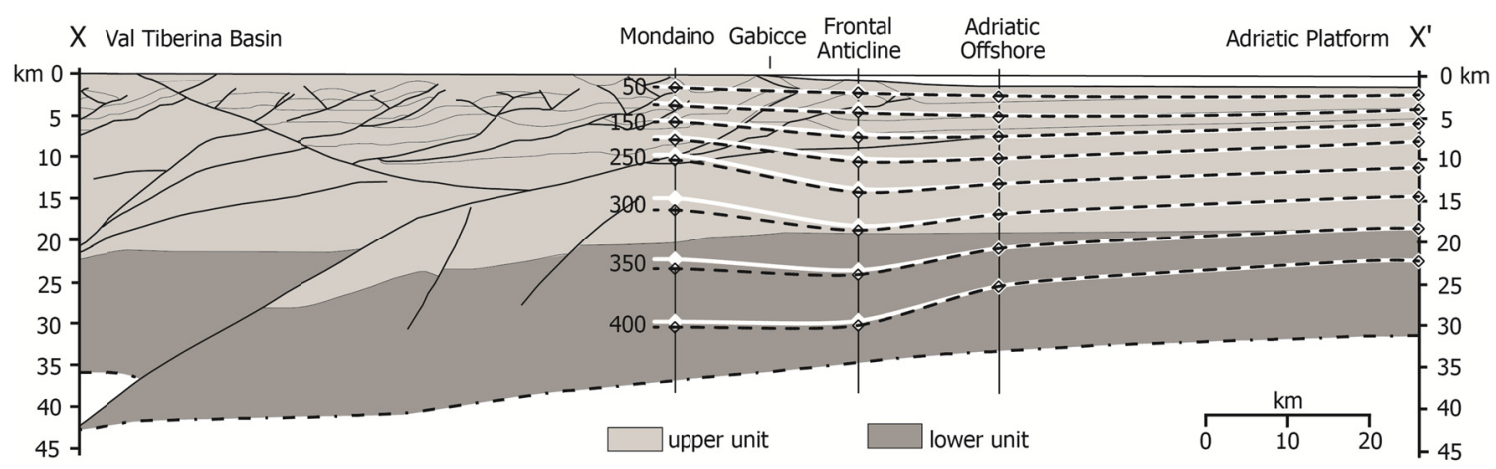

Figure 5. Thermal structure for the study area as defined by isotherms produced by the interpolation among four vertical temperature profiles (white isotherms are for active thrusting; see text) 


\section{References}

Bally A. W., Burbi L., Cooper C., \& Ghelardoni R. (1986). Balanced sections and seismic reflection profiles across the Central Apennines. Mem. Soc. Geol. It., 52, 527-538.

Barchi, M. R., De Feyter, A., Magnani, M. B., Minelli, G., \& Sotera, B. M. (1998). Extensional tectonics in the Northern Apennines (Italy): Evidence from the CROP03 deep seismic reflection line. Mem. Soc. Geol. It., 52, 527-538.

Barchi, M. R., Minelli, G., Magnani, M. B., \& Mazzotti, A. (2003). Line CROP 03: Northern Apennines. Mem. Descr. Carta Geol. d'It., 62, 127-136.

Basili, R., \& Barba, S. (2007). Migration and shortening rates in the northern Apennines, Italy: implications for seismic hazard. Terra Nova, 19, 462-468. http://dx.doi.org/10.1111/j.1365-3121.2007.00772.x

Butler, R. W. H., \& Mazzoli, S. (2006). Styles of continental contraction: A review and Introduction. In: Styles of Continental Contraction (Mazzoli S. \& Butler R.W.H., eds.), Geological Society of America, Special Paper, 414, 1-10. http://dx.doi.org/10.1130/2006.2414(01)

Candela, S., Mazzoli, S., Megna, A., \& Santini, S. (2014). Thermal structure of the southern Apennines along the Val d'Agri-Bari transect. Rend. Online Soc. Geol. It., 32, 3-6. http://dx.doi.org/10.3301/ROL.2014.141

Candela, S., Mazzoli, S., Megna, A., \& Santini, S. (2015). Finite element modeling of stress field perturbations and interseismic crustal deformation in the Val d'Agri region, southern Apennines, Italy. Tectonophysics, 657, 245-259. http://dx.doi.org/10.1016/j.tecto.2015.07.011

Coward, M. P., De Donatis, M., Mazzoli, S., Paltrinieri, W., \& Wezel, F. C. (1999). Frontal part of the Northern Apennines fold and thrust belt in the Romagna-Marche area (Italy): Shallow and deep structural styles. Tectonics, 18, 559-574. http://dx.doi.org/10.1029/1999TC900003

Di Bucci, D., Mazzoli, S., Nesci, D., Savelli, D., Tramontana, M., De Donatis, M., \& Borraccini, F. (2003). Active deformation in the frontal part of the Northern Apennines: insights from the lower Metauro River basin area (northern Marche, Italy) and adjacent Adriatic off-shore. Journal of Geodynamics, 36, 213-238. http://dx.doi.org/10.1016/S0264-3707(03)00048-6

Di Bucci, D., \& Mazzoli, S. (2003). The October-November 2002 Molise seismic sequence (southern Italy): an expression of Adria intraplate deformation. J. Geol. Soc. London, 160, 503-506. http://dx.doi.org/10.1144/0016-764902-152

DISS Working Group. (2010). Database of Individual Seismogenic Sources (DISS), Version 3.1.1: A compilation of potential sources for earthquakes larger than $M 5.5$ in Italy and surrounding areas. http://diss.rm.ingv.it/diss/, (C) INGV 2010 - Istituto Nazionale di Geofisica e Vulcanologia.

Kastelic, V., Vannoli, P., Burrato, P., Fracassi, U., Tiberti, M. M., \& Valensise, G. (2013). Seismogenic sources in the Adriatic Domain. Marine Petrol. Geol., 42, 191-213. http://dx.doi.org/10.1016/j.marpetgeo.2012.08.002

Mazzoli, S., Lanci, L., \& De Donatis, M. (2001). Paleomagnetic rotations in thrust belts: A case-study from the Marche-Romagna area (Northern Apennines, Italy). Journal of Geodynamics, 32, $373-393$. http://dx.doi.org/10.1016/S0264-3707(01)00037-0

Mazzoli, S., Macchiavelli, C., \& Ascione, A. (2014). The 2013 Marche offshore earthquakes: new insights into the active tectonic setting of the outer northern Apennines. J. Geol. Soc. London, 171, 457-460. http://dx.doi.org/10.1144/jgs2013-091

Mazzoli, S., Pierantoni, P. P., Borraccini, F., Paltrinieri, W., \& Deiana, G. (2005). Geometry, segmentation pattern and displacement variations along a major Apennine thrust zone, central Italy. Journal of Structural Geology, 27, 1940-1953. http://dx.doi.org/10.1016/j.jsg.2005.06.002

Mazzoli, S., Santini, S., Macchiavelli, C., \& Ascione, A. (2015). Active tectonics of the outer northern Apennines: Adriatic vs. Po Plain seismicity and stress fields. Journal of Geodynamics, 84, 62-76. http://dx.doi.org/10.1016/j.jog.2014.10.002

Megna, A., Candela, S., Mazzoli, S., \& Santini, S. (2014). An analytical model for the geotherm in the Basilicata oil fields area (southern Italy). Ital. J. Geosci., 133, 204-213. http://dx.doi.org/10.3301/IJG.2014.02

Molnar, P., Chen, W. P., \& Padovani, E. (1983). Calculated temperatures in overthrust terrains and possible combinations of heat sources responsible for the tertiary granites in the greater Himalaya. J. Geophys. Res., 88, 6415-6429. http://dx.doi.org/10.1029/JB088iB08p06415 
Mongelli, F., Minelli, G., \& Loddo, M. (2006). Geodynamics, thermal structure and depth of the brittle and semi-brittle layers in the Northern Apennine (Italy). Boll. Geofis. Teor. App., 47, 375-399.

Morgante, A., Barchi, M. R., D’Offizi S., Minelli, G., \& Pialli G. (1998). The contribution of seismic modeling of the interpretation of the CROP-03 line. Mem. Soc. Geol. It., 52, 441-455.

Santini, S., Saggese, F., Megna, A., \& Mazzoli, S. (2011). A note on central-northern Marche seismicity: new focal mechanisms for events recorded in years 2003-2009. Boll. Geofisica Teorica ed Applicata, 52, 639-649. http://dx.doi.org/10.4430/bgta0025

Scrocca, D., Doglioni, C., \& Innocenti, F. (2003). Constraints for an interpretation of the Italian geodynamics: A review. Mem. Descr. Carta Geol. d'It., 62, 15-46.

Sibson, R. H. (1974). Frictional constraints on thrust, wrench and normal faults. Nature, 249, 542-544. http://dx.doi.org/10.1038/249542a0

Tozer, R. S. J., Butler, R. W. H., Chiappini, M., Corrado, S., Mazzoli, S., \& Speranza, F. (2006). Testing thrust tectonic models at mountain fronts: where has the displacement gone? J. Geol. Soc. London, 162, 1-14. http://dx.doi.org/10.1144/0016-764904-140

Vannoli, P., Basili, R., \& Valensise, G. (2004). New geomorphic evidence for anticlinal growth driven by blind faulting along the northern Marche coastal belt (Central Italy). J. Seismol., 8, 297-312. http://dx.doi.org/10.1023/B:JOSE.0000038456.00574.e3

\section{Copyrights}

Copyright for this article is retained by the author(s), with first publication rights granted to the journal.

This is an open-access article distributed under the terms and conditions of the Creative Commons Attribution license (http://creativecommons.org/licenses/by/4.0/). 